\title{
BIODIVERSITY AND DISTRIBUTION OF ARBUSCULAR MYCORRHIZAL FUNGI IN Araucaria angustifolia FOREST
}

\author{
Milene Moreira ${ }^{1 *}$; Dilmar Baretta ${ }^{2}$; Siu Mui Tsai ${ }^{3}$; Sandra Maria Gomes-da-Costa4; Elke \\ Jurandy Bran Nogueira Cardoso ${ }^{5}$ \\ ${ }^{1}$ APTA - Pólo Regional Médio Paranapanema, C.P. 263 - 19800-970 - Assis, SP - Brasil. \\ ${ }_{3}^{2} U S P / E S A L Q$ - Programa de Pós-Graduação em Solos e Nutrição de Plantas \\ ${ }^{3}$ USP/CENA - Laboratório de Microbiologia e Biologia Molecular - 13416-000 - Piracicaba, SP - Brasil. \\ ${ }^{4}$ UEM - Depto. de Biologia - 87090-900 - Maringá, PR - Brasil. \\ ${ }^{5}$ USP/ESALQ - Depto. de Ciência do Solo, C.P. 09 - 13418-900 - Piracicaba, SP - Brasil. \\ *Corresponding author 〈mmoreira@aptaregional.sp.gov.br>
}

\begin{abstract}
Araucaria angustifolia (Bert.) O. Ktze. is an endangered Brazilian coniferous tree that has been almost exterminated in the native areas because of uncontrolled wood exploitation. This tree has been shown to be highly dependent on arbuscular mycorrhizal fungi (AMF) and, therefore, AMF may be essential for forest sustainability and biological diversity. Root colonization, density and diversity of AMF spores were assessed in two Araucaria forest stands at the State Park of Alto Ribeira (PETAR), at two sampling dates: May and October. A comparison was made between a mature native stand composed of Araucaria trees mixed into a variety of tropical trees and shrubs, without any sign of anthropogenic interference (FN) and an Araucaria stand planted in 1987 (R), which has been used as a pasture. Assessments included percent root colonization, AMF spore numbers and species richness, Simpson's dominance index (Is), and Shannon's diversity index (H). Mycorrhizal root colonization did not differ between ecosystems in May. In October, however, the native stand (FN) presented a higher colonization than the planted forest (R), and the root colonization was more intense than in May. When considering both sampling periods and forests, 27 species of AM fungi, with higher numbers of spores in $\mathrm{FN}$ than in $\mathrm{R}$ were found. Canonical discriminant analysis (CDA) indicated Shannon's diversity index as the ecological attribute that contributed the most to distinguish between forest ecosystems, with higher value of $\mathrm{H}$ in $\mathrm{FN}$ in relation to $\mathrm{R}$. CDA showed to be a useful tool for the study of ecological attributes.
\end{abstract}

Key words: Brazilian Pine, diversity, spore density, root colonization, multivariate analysis

\section{BIODIVERSIDADE E DISTRIBUIÇÃO DE FUNGOS MICORRÍZICOS ARBUSCULARES EM FLORESTA DE Araucaria angustifolia}

\footnotetext{
RESUMO: O pinheiro brasileiro, Araucaria angustifolia (Bert.) O. Ktze é uma espécie arbórea ameaçada de extinção, quase exterminada pela exploração descontrolada de madeira. Essa espécie demonstra alta dependência de fungos micorrízicos arbusculares (FMA), de grande importância para a estabilidade do ecossistema e manutenção da biodiversidade. Avaliou-se a colonização radicular, a densidade e a diversidade de esporos de FMA em duas florestas com araucária, distintas no processo sucessional, em duas épocas de amostragem: maio e outubro. As florestas, localizadas no Parque Estadual Turístico do Alto do Ribeira (PETAR), correspondem a 1) Floresta Ombrófila Mista nativa (FN), em estágio clímax, sem sinais de interferência antrópica, e a 2) floresta de araucária plantada em 1987 (R), submetida a pastoreio. Foram avaliados: colonização radicular, número de esporos e riqueza de espécies de FMA e calculados os índices de dominância de Simpson (Is) e de diversidade de Shannon $(\mathrm{H})$. A colonização radicular não diferiu entre as duas comunidades na primeira amostragem (maio). Na segunda amostragem (outubro), houve maior colonização radicular na floresta nativa do que na floresta plantada e a colonização radicular foi mais intensa em comparação com as coletas de maio. No total, foram encontradas 27 espécies de FMA, com maior número de esporos em FN em relação a R. A análise canônica discriminante (ACD) indicou que o índice de diversidade de Shannon foi o atributo ecológico que mais contribuiu para distinguir os dois ecossistemas florestais, com altos valores de H para FN em relação a R. ACD mostrou ser importante ferramenta para o estudo dos atributos ecológicos.

Palavras-chave: Araucaria angustifolia, diversidade, densidade de esporos, colonização radicular, análise multivariada
} 


\section{INTRODUCTION}

The presence of arbuscular mycorrhizal fungi (AMF) may be essential for ecosystem sustainability, establishment of plants and maintenance of biological diversity. The participation of AMF in the biodiversity and ecosystem functioning is now being recognized, particularly due to their effect on plant diversity and productivity (van der Heijden et al., 1998). Several authors have reported positive relationships between plant diversity and AMF colonization (Grime et al., 1987; van der Heijden et al., 1998).

Mycorrhizal fungi are one of the main pathways by which most plants obtain nutrients (Smith \& Barker, 2002; Chen et al., 2005) and, as such, are critical for terrestrial ecosystem functioning (Kernaghan, 2005). The success of reforestation programs may greatly depend on mycorrhizal root colonization of seedlings, which increases their competitiveness due to increase in the initial growth rate (Moreira-Souza $\&$ Cardoso, 2002). In that sense, the rehabilitation of tropical forests would not be possible only with chemical fertilizers but would also need AMF inoculation (Cuenca et al., 1998).

Historically, there are only few reports on the occurrence of AMF in association with Araucaria angustifolia (Brazil Pine) (Milanez \& Monteiro, 1950; Oliveira \& Ventura, 1952; Bononi et al., 1989; Andrade et al., 2000). Recently it was shown that Araucaria is highly mycotrophic (Moreira-Souza \& Cardoso, 2002; Zandavalli et al., 2004), and different AMF species, distributed among the genera Glomus, Acaulospora, Entrophosphora, Gigaspora and Scutellospora, have been found associated to Brazil Pine roots (MoreiraSouza et al., 2003).

The objective of the present study was to compare the mycorrhizal root colonization, density and diversity of AMF, between Araucaria Forest stands which differ in the conservation status: one is native, and the other is a planted stand under pressure by cattle grazing.

\section{MATERIAL AND METHODS}

The sampling sites are located in the Atlantic Forest of altitude (Ombrophilous Mixed Forest, ac- cording to IBGE, 1992) where Araucaria angustifolia (Bertoloni) Otto Kuntze is of natural occurrence. Two subareas (natural and reforested) were selected in the State Park of Alto do Ribeira (PETAR) (24 20 'S and $\left.48^{\circ} 36^{\prime} \mathrm{W}\right)$, located in the municipality of Apiaí, State of São Paulo, Brazil. The local climate is Cfb (Köppen's classification), characterized as subtropical (upland), mesothermal, and humid. The mean temperature during 2002 was $21.1^{\circ} \mathrm{C}$. Summer and winter were mild, with little rain between May and August, and rainy from October to March.

The experimental design consisted of a completely randomized layout, with 15 replicates, considering two forest ecosystems: i) a native stand, mixed climax forest with Araucaria trees, without anthropogenic interference (FN), basically consisted of A. angustifolia and other shrub or tree species, as Ocotea sp., Nectandra sp., Cedrella fissilis, Ficus sp., Hymenaea courbaril, Virola oleifera, Euterpe edulis, as well as many epiphytic species as orchids and bromeliads; and ii) reforested stand, exclusively with Araucaria, replanted in 1987 (R). This area has suffered anthropogenic interference due to subsistence agriculture and use as pasture for cattle and horses. Remains of some pasture grasses and Tibouchina granulosa trees, typical of secondary vegetation, can also be found.

Each selected forest ecosystem was represented by one plot, approximately 0.5 ha in size, where five Araucaria trees were randomly selected. For each tree, three soil and root samples were taken (0-0.2 m) at the crown projection and $2 \mathrm{~m}$ away from the tree trunk. Root samples were washed in tap water and stored in FAA fixative (glacial acetic acid $25 \mathrm{~mL}$; ethanol $500 \mathrm{~mL}$, formaldehyde $120 \mathrm{~mL}$, and distilled water $1000 \mathrm{~mL}$ ) before assesment of AMF colonization. Soil from the root zone $(500 \mathrm{~g})$ and Araucaria roots were sampled in May (cool, dry season) and October (warm, rainy season) in the year 2002. Some soil chemical and physical characteristics were assessed in each area (Table 1).

AMF spores were extracted from soil samples by wet sieving (Gerdemann \& Nicolson, 1963), based on a $100 \mathrm{~g}$ soil aliquot taken from each sample, followed by centrifugation in sucrose (Jenkins, 1964).

Table 1 - Chemical and physical soil characteristics in native (FN) and reforested (R) Araucaria angustifolia ecosystems. May 2002, PETAR, Apiaí, SP, Brazil.

\begin{tabular}{|c|c|c|c|c|c|c|c|c|c|c|}
\hline Ecosystem & $\begin{array}{c}\mathrm{pH} \mathrm{CaCl} \\
0.01 \mathrm{~mol} \mathrm{~L}^{-1}\end{array}$ & $\mathrm{OM}$ & $\begin{array}{c}\mathrm{P} \\
\text { (resin) }\end{array}$ & $\mathrm{K}$ & $\mathrm{Ca}$ & $\mathrm{Mg}$ & $\mathrm{H}+\mathrm{Al}$ & Sand & Silt & Clay \\
\hline & & $\mathrm{g} \mathrm{dm}^{-3}$ & $\mathrm{mg} \mathrm{dm}^{-3}$ & \multicolumn{4}{|c|}{ - mmol $\mathrm{dm}^{-3} \mathrm{-}$} & \multicolumn{3}{|c|}{ - } \\
\hline FN & 4.7 & 115 & 30 & 2.8 & 102 & 20 & 64 & 510 & 200 & 290 \\
\hline $\mathrm{R}$ & 3.4 & 95 & 13 & 2.5 & 14 & 7 & 281 & 260 & 250 & 490 \\
\hline
\end{tabular}

$\mathrm{OM}=$ organic matter 
The spores were counted under a stereomicroscope of 40x magnification, on plates containing concentric grooves. After counting, the spores were separated into groups, according to their morphology.

For morphological identification, groups of AMF spores were mounted onto semi-permanent slides, with polyvinyl alcohol and glycerol resin (PVLG) (Morton et al., 1993) and in Melzer's reagent (Koske \& Tessier, 1983). Identification at the species level was performed using the optical microscope (100 to 400x magnifications), with the aid of the Schenck \& Pérez's (1990) Manual and descriptions provided by the International Culture Collection of Vesicular Arbuscular Mycorrhizal Fungi (http://invam.caf.wvu.edu) and the original species descriptions.

For assessment of mycorrhizal colonization, roots were cleared in $10 \% \mathrm{KOH}$ and $10 \% \mathrm{H}_{2} \mathrm{O}_{2}$, and stained with pen blue ink in acetic acid (Vierheilig et al., 1998). The presence of fungal structures within the roots was observed under the microscope (400x) (Giovannetti \& Mosse, 1980).

The ecological attributes were calculated in the following manner: total and relative frequency (RF) of AMF spores $[R F=$ (number of spores of each species/total number of spores) $\times 100$ ], species richness (number of species in $100 \mathrm{~g}$ dry soil), Simpson's dominance index (Is) and Shannon's diversity index (H) (Mouillot \& Leprêtre, 1999). Data for total number of spores were submitted to analysis of variance (ANOVA) and means were compared by the LSD test $(P<0.05)$. In addition, the multivariate Canonical Discriminating Analysis (CDA) (SAS Institute, 1996) was applied to verify which ecological attribute contributed the most to distinguish between the ecosystems (FN and R). Calculations were made for the homogenized canonical coefficient (HCC), coefficient of correlation $(r)$, and parallel discrimination rate coefficient (PDRC $=r \times$ HCC) (Cruz-Castillo et al., 1994).

\section{RESULTS AND DISCUSSION}

The soils under study are acid in both Araucaria angustifolia stands. In the native forest, however, the soil was more fertile, with higher organic matter, phosphorus, calcium, and magnesium concentrations in relation to the soil under the planted forest (Table 1). At the first sampling (May), there were no differences in mycorrhizal root colonization rates (RC) between the two ecosystems (FN and R). Their values ranged from $17.2 \%$ in the native forest to $15.2 \%$ in the planted stand (Figure 1). At the second sampling (October), the mycorrhizal root colonization increased in both forests (up to $36 \%$ in the native and up to $31 \%$ in the planted stand), and differed consid- erably from the first period: roots from FN presented more than twice the colonization rate verified at the first sampling (Figure 1). Similar mycorrhizal colonization levels were found in native and reforested Araucaria stands in another geographical location, in the same region (Moreira-Souza et al., 2003; 2006).

The number of spores in the root zone of Araucaria was always greater in the native than in the reforested area in both sampling periods (Table 2). No seasonality pattern could be detected for number of spores, with a mean count close to 400 spores (in 100 $\mathrm{g}$ of soil) for the native and 158 to 269 spores for the reforested area (Table 2). However, in another survey conducted simultaneously, in native and replanted Araucaria forests in Campos do Jordão - SP, more AMF spores were found in the replanted areas than in the native ones (Moreira et al., 2006). Therefore, the assumption that spores should be more abundant in areas without disturbance is not always true.

Fungal diversity and abundance found in the study area are similar to those of other studies in the Araucaria forests and Atlantic Forest of São Paulo State (Bononi et al., 1989; Trufem, 1990; Breuninger et al., 2000; Moreira-Souza et al., 2003; Aidar et al., 2004). Twenty-seven taxa belonging to the Glomerales (Glomeromycota) were identified; 21 at the species level, and six at the genus level (Table 2). In a previous study, 24 AMF species were found in Araucaria forests in Campos do Jordão - SP (Moreira-Souza et al., 2003). However, in the very south of Brazil, only 13 species were identified in Araucaria ecosystems (Breuninger et al., 2000).

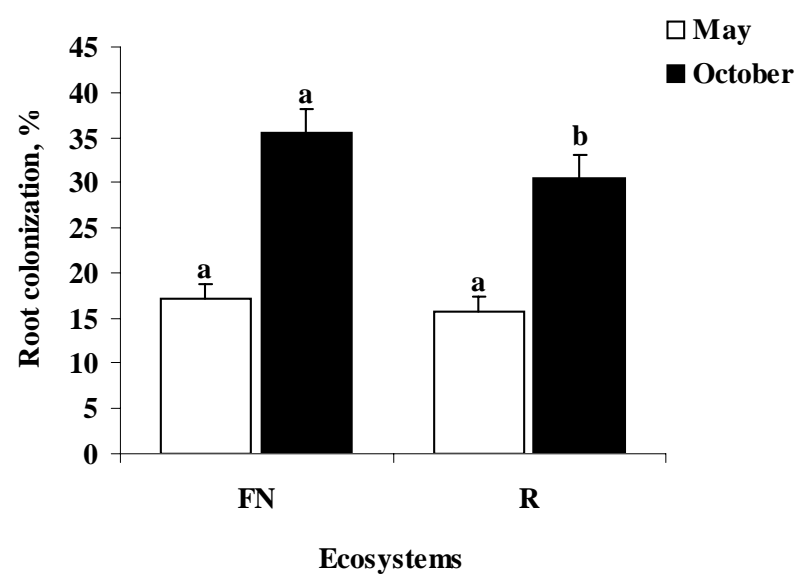

Figure 1 - Arbuscular mycorrhizal fungal root colonization of Araucaria angustifolia sampled in native (FN) and reforested (R) ecosystems, in May and October 2002. PETAR, Apiaí, SP, Brazil. Vertical bars on the columns represent standard deviation of 15 replications. Means indicated by the same letters in columns do not differ $(P<0.05)$ by the LSD test, considering the same sampling date. 
Table 2 - Absolute (AF) and relative (RF) frequencies of AMF spores in native (FN) and reforested (R) Araucaria angustifolia ecosystems, in May and October 2002. PETAR, Apiaí, SP, Brazil $(n=15)$.

\begin{tabular}{|c|c|c|c|c|c|c|c|c|}
\hline \multirow{3}{*}{ AMF species } & \multicolumn{4}{|c|}{ May 2002} & \multicolumn{4}{|c|}{ October 2002} \\
\hline & \multicolumn{2}{|c|}{ FN } & \multicolumn{2}{|c|}{$\mathrm{R}$} & \multicolumn{2}{|c|}{ FN } & \multicolumn{2}{|c|}{$\mathrm{R}$} \\
\hline & $\mathrm{AF}$ & $\mathrm{RF}$ & $\mathrm{AF}$ & RF & $\mathrm{AF}$ & $\mathrm{RF}$ & $\mathrm{AF}$ & $\mathrm{RF}$ \\
\hline $\begin{array}{l}\text { Acaulospora bireticulata Rothwell \& } \\
\text { Trappe }\end{array}$ & 2 & 0.5 & 6 & 2.2 & -(1) $^{(1)}$ & - & - & - \\
\hline A. foveata Trappe \& Janos & 12 & 3.1 & 12 & 4.5 & 3 & 0.8 & - & - \\
\hline A. koskei Blaszkowski & - & - & - & & - & - & 6 & 3.8 \\
\hline A. laevis Gerd. \& Trappe & - & - & - & - & - & - & 2 & 1.3 \\
\hline A. longula c.f. & - & - & - & - & - & - & 4 & 2.5 \\
\hline A. mellea Spain \& Schenck & - & - & 24 & 8.9 & 85 & 21.6 & 6 & 3.8 \\
\hline A. morrowiae Spain \& Schenck & - & - & 4 & 1.5 & - & - & 10 & 6.3 \\
\hline A. scrobiculata Trappe & 60 & 15.5 & 14 & 5.2 & - & - & - & - \\
\hline A. spinosa Walker \& Trappe & 12 & 3.1 & 10 & 3.7 & 16 & 4.1 & 3 & 1.9 \\
\hline Acaulospora sp. 1 & 10 & 2.6 & 8 & 3.0 & 5 & 1.3 & - & - \\
\hline Acaulospora sp. 2 & 10 & 2.6 & - & - & 14 & 3.6 & - & - \\
\hline Acaulospora sp. 3 & 8 & 2.1 & 14 & 5.2 & - & - & - & - \\
\hline $\begin{array}{l}\text { Archeospora gerdemannii (Rose, } \\
\text { Daniels \& Trappe) Morton \& Redecker }\end{array}$ & 10 & 2.6 & 28 & 10.4 & - & - & - & - \\
\hline $\begin{array}{l}\text { Entrophospora colombiana Spain \& } \\
\text { Schenck }\end{array}$ & 2 & 0.5 & - & - & 18 & 4.6 & 22 & 13.9 \\
\hline E. kentinensis Wu \& Liu & 6 & 1.6 & - & - & - & - & - & - \\
\hline Gigaspora decipiens Hall \& Abbott & - & - & 6 & 2.2 & 3 & 0.8 & - & - \\
\hline G. margarita Becker \& Hall & 36 & 9.3 & 4 & 1.5 & - & - & - & - \\
\hline Glomus diaphanum Morton \& Walker & - & - & - & - & - & - & 5 & 3.2 \\
\hline G. etunicatum Becker \& Gerd. & 20 & 5.2 & 2 & 0.7 & 92 & 23.4 & 8 & 5.1 \\
\hline G. geosporum (Nicol. \& Gerd.) Walker & - & - & - & - & - & - & 8 & 5.1 \\
\hline G. macrocarpum Tul. \& Tul. & 182 & 47.2 & 121 & 45.0 & 105 & 26.7 & 44 & 27.8 \\
\hline G.microcarpum Gerd. \& Trappe & - & - & - & - & 14 & 3.6 & 32 & 20.3 \\
\hline Glomus sp. 1 & 4 & 1.0 & - & - & 18 & 4.6 & 8 & 5.1 \\
\hline $\begin{array}{l}\text { Scutellospora heterogama Nicol. \& } \\
\text { Gerd. }\end{array}$ & 2 & 0.5 & - & - & - & - & - & - \\
\hline $\begin{array}{l}\text { S. pellucida (Nicol. \& Schenck) Walker } \\
\text { \& Sanders }\end{array}$ & 6 & 1.6 & 16 & 5.9 & - & - & - & - \\
\hline Scutellospora sp.1 & 4 & 1.0 & - & - & 6 & 1.5 & - & - \\
\hline Scutellospora sp.2 & - & - & - & - & 14 & 3.6 & - & - \\
\hline Total number of AMF spores & 386 a & & $269 \mathrm{~b}$ & & 393 a & & $158 \mathrm{~b}$ & \\
\hline Total species richness & 17 & & 14 & & 13 & & 13 & \\
\hline Shannon's diversity index $(\mathrm{H})$ & 1.20 & & 1.03 & & 1.01 & & 0.87 & \\
\hline Simpson's dominance index (Is) & 0.64 & & 0.59 & & 0.57 & & 0.51 & \\
\hline
\end{tabular}

${ }^{1}$ Absence of AMF. Means followed by the same letter in line, considering the same sampling time, do not differ $(P<0.05)$ by the LSD test.

In the present study, the genus Acaulospora had the highest species diversity, whereas Glomus presented the highest number of spores. The genus Gigaspora occurred in lower fequency, mostly in the native area (Table 2). The species Acaulospora spinosa, Glomus etunicatum and Glomus macrocarpum were present in both areas in May and in October. However, the frequency of the different AMF species was peculiar for each ecosystem and sampling period. In the native forest, the most frequently found species were G. macrocarpum, Acaulospora scrobiculata, and Gigaspora margarita in May, whereas in October the 
predominance of G. macrocarpum, Glomus etunicatum, and Acaulospora mellea was noticed. In the reforested area, the most frequent species were: Glomus macrocarpum, Acaulospora mellea, and Archeospora gerdemannii in May, and G. macrocarpum, G. microcarpum and Entrophospora colombiana in October (Table 2). G. macrocarpum was always the species with the greatest frequency in both areas, suggesting that this species is well adapted to this host plant and shows high tolerance to different edaphic conditions. G. macrocarpum and G. etunicatum have been reported as dominant species in other studies conducted in the Atlantic Forest (Trufem, 1990; Aidar et al., 2004). A recent study identified 25 AMF species associated with several tree species in the same State Park of PETAR, ten of which identical to our findings (Aidar et al., 2004).

In this study, when considering both sampling periods, the total number of spores, species richness, and Shannon's diversity index $(\mathrm{H})$ were higher in the native forest than in the planted stand (Table 2). The higher value of $\mathrm{H}$ in the FN area reflects greater species diversity (Table 2). These findings can probably be explained by better soil chemical properties of this area with regard to organic matter, $\mathrm{pH}, \mathrm{Ca}$ and $\mathrm{Mg}$ (Wardle, 2002; Kernaghan, 2005) (Table 1). Moreover, there is a greater richness of plant species (van der Heijden et al., 1998), as well as older plants, especially Araucaria trees. In addition, the general absence of anthropogenic disturbance (Kernaghan, 2005) and greater diversity of plants (Johnson et al., 2003) in the native forest may also have favored the higher AMF diversity. The different seasons, with different temperature and moisture regimes, may affect AM fungal sporulation (Koske, 1987), and a greater number of spores was found in the planted area in May as compared to October. This finding provides support to the view that death or senescence of the host plant induces AMF to sporulate (Picone, 2000).

The canonical discriminating analysis (CDA) presented a correlation of $88 \%$ in the first canonical discriminating function (FDC1). This function can be fitted to explain variations in number of spores, species richness, Simpson's dominance index (Is) and Shannon's diversity index $(\mathrm{H})$ obtained in the two Araucaria ecosystems (Table 3) (Manly, 1994). In our study, which compared only two areas, it was possible to generate only one canonical discriminating function (Cruz-Castillo et al., 1994) (Table 3).

The multivariate Wilks' Lambda test showed that there is a highly significant difference between these two ecosystems $(P<0.0001)$, a result that could be confirmed by the LSD $(P<0.05)$, existing among all the homogenized canonical coefficients (HCC) (Fig- ure 2). The native forest presented a much higher mean (1.8338) against (-1.6046) of the planted stand, considering the FDC1 axis. Therefore, the conventional univariate statistical analysis can be helpful in understanding the ecological significance of multivariate analyses.

The coefficients of correlation $(r)$ reflect univariate information and show the individual contribution of each ecological attribute in the separation of the two Araucaria ecosystems (Table 3 and Figure 2). The homogenized canonical coefficient (HCC) explains the behavior of the different attributes in allowing the ecosystems to be separated from each other, under a multivariate point of view. However, the index known

Table 3 - Coefficient of correlation $(r)$, homogenized canonical coefficient (HCC) and parallel discrimination rate coefficient $(\mathrm{PDRC}=r \times \mathrm{HCC})$ of the first discriminating canonical function (FDC1) for each ecological attribute, in native (FN) and reforested (R) Araucaria angustifolia ecosystems, in May and October 2002. PETAR, Apiaí, SP, Brazil $(\mathrm{n}=30)$.

\begin{tabular}{|c|c|c|c|}
\hline \multirow{2}{*}{ Attribute } & \multicolumn{3}{|c|}{ FDC1 } \\
\hline & $\mathrm{r}$ & $\mathrm{HCC}$ & PDRC \\
\hline Number of spores & -0.2340 & -0.0039 & 0.0009 \\
\hline Species richness & 0.1111 & -0.4510 & -0.0501 \\
\hline $\begin{array}{l}\text { Simpson's dominance } \\
\text { index (Is) }\end{array}$ & 0.0622 & 0.2877 & 0.0179 \\
\hline $\begin{array}{l}\text { Shannon's diversity } \\
\text { index }(\mathrm{H})\end{array}$ & 0.9808 & 1.0514 & 1.0312 \\
\hline
\end{tabular}

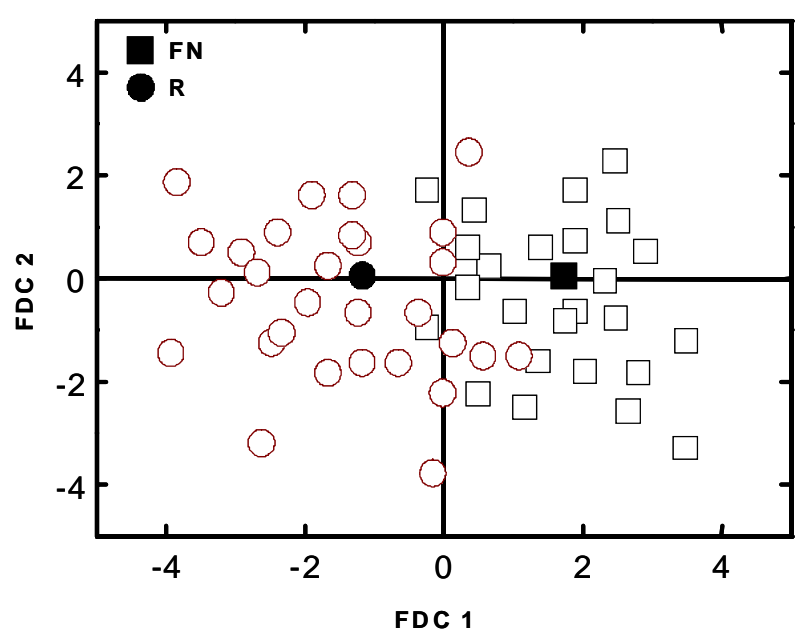

Figure 2 - Relationships between the first and the second discriminating canonical functions (FDC1 and FDC2) on the homogenized canonical coefficient (HCC) for the ecological attributes in native (FN) and reforested (R) Araucaria angustifolia ecosystems, in May and October 2002. PETAR, Apiaí, SP, Brazil $(n=30)$. Mean points are represented in black. 
as parallel discrimination rate coefficient (PDRC), which represents the product between the $\mathrm{HCC}$ and $r$ coefficients, is usually adopted (Cruz-Castillo et al., 1994). Positive PDRC values indicate a separation effect between the two Araucaria ecosystems, where ecological attributes with higher values have greater weight in the separation (Table 3 and Figure 2). In this case, $\mathrm{H}$ showed the highest $r(0.9808)$ and HCC (1.0514) figures that resulted in higher PDRC (1.0312) values (Table 3). This indicates that in the sum of all attributes, Shannon's index was responsible for practically the entire separation between the two Araucaria ecosystems, and is therefore a good indicator of the changes that occur in the ecosystem. In this sense, $\mathrm{H}$ can be considered a valuable attribute in the ecological discrimination among forest ecosystems with different histories of use or management. Shannon's index $(\mathrm{H})$ is an indicator of AM fungal diversity, reflecting the complexity level of the communities in each ecosystem. In addition, this estimator of species diversity is sensitive to changes in species abundance pattern and presents a low bias for small sample sizes (Mouillot \& Leprêtre, 1999). In this respect, AMF density and species diversity are indirectly related to the ecological conditions of each ecosystem (Maia \& Trufem, 1990). $\mathrm{H}$ has been reported as an indicator of differentiation between areas with different management and seems to be a promising indicator in relation to other biological attributes, which are generally harder to measure and are more costly (Parr et al., 1992).

The finding that there are significant ecological differences between the native forest and the planted stand suggests that, even after 18 years of reforestation, the original AMF diversity of the native area could not be recuperated. According to this reasoning, the maintenance of the few still preserved native forests and also the replanting of new Araucaria seedlings with their symbiotic AM fungi assume great importance for the conservation of this species. The canonical discriminating analysis proved to be a very useful tool in detecting differences in the community of AMF in Araucaria forests.

\section{ACKNOWLEDGEMENTS}

To FAPESP for the post-doctoral grant to M. Moreira (process no. 01/13229-9) and financial support (process no. 01/05146-6 in the Biota Program). To Antonio Modesto Pereira and Tadeu Gonçalves at the Tourist State Park of Alto Ribeira (PETAR), in Apiaí, State of São Paulo, Brazil, and to the Environmental Secretariat of the State of São Paulo for authorizing the sampling of plant material (Proceeding
40405/98 COTEC 079/98). Thanks are also due to Denise L. Mescolotti and Luis Fernando Baldesin for technical assistance, and to Dr. Marco Antonio Nogueira (UEL/PR) for critical review of the text. E.J.B.N. Cardoso, D. Baretta and S.M. Tsai thank CNPq for the research fellowship.

\section{REFERENCES}

AIDAR, M.P.M.; CARRENHO, R.; JOLY, C.A. Aspects of arbuscular mycorrhizal fungi in an Atlantic Forest chronosequence in Parque Estadual Turístico do Alto Ribeira (PETAR), SP. Biota Neotropica, v.4, p.1-15, 2004.

ANDRADE, A.C.S.; QUEIROZ, M.H.; HERMES, R.A.; OLIVEIRA, V.L. Mycorrhizal status of some plants of the Araucaria forest and the Atlantic rainforest in Santa Catarina, Brazil. Mycorrhiza, v.10, p.131-136, 2000.

BONONI, V.L.R.; GRANDI, R.A.P.; LOPES, S.A.R.; RODRIGUES, E.; FONSECA, M.P. Micorrizas vesiculo-arbusculares em Araucaria angustifolia (Bert.) O. Ktze In: REUNIÃO BRASILEIRA SOBRE MICORRIZAS, 3., Piracicaba, 1989. Livro de resumos. Piracicaba: CENA; ESALQ, 1989.

BREUNinger, M.; EINIG, W.; MAGEL, E.; CARDOSO, E.; HAMPP, R. Mycorrhiza of Brazil Pine (Araucaria angustifolia Bert. O. Ktze.). Plant Biology, v.2, p.4-10, 2000.

CHEN, X.; TANG, J.; ZHI, G.; HU, S. Arbuscular mycorrhizal colonization and phosphorus acquisition of plants: effects of coexisting plant species. Applied Soil Biology, v.28, p.259269, 2005.

CRUZ-CASTILLO, J.G.; GANESHANANDAM, S.; MACKAY, B.R.; LAWES, G.S.; LAWOKO, C.R.O.O.; WOOLLEY, D.J. Applications of canonical discriminant analysis in horticultural research. HortScience, v.29, p.1115-1119, 1994.

CUENCA, G.; ANDRADE, Z.; ESCALANTE, G. Diversity of Glomalean spores from natural, disturbed and revegetated communities growing on nutrient-poor tropical soils. Soil Biology and Biochemistry, v.30, p.711-719, 1998.

GERDEMANN, J.W.; NICOLSON, T.H. Spores of mycorrhizal Endogone species extracted from soil by wet sieving and decanting. Transactions of the British Mycological Society, v.46, p.235-246, 1963.

GIOVANNETTI, M.; MOSSE, B. An evaluation of techniques for measuring vesicular arbuscular mycorrhizal infection in roots. New Phytologist, v.84, p.489-500, 1980.

GRIME, J.P.; MACKEY, J.M.L.; HILLIER, S.H.; READ, D.J. Floristic diversity in a model system using experimental microcosms. Nature, v.328, p.420-422, 1987.

INSTITUTO BRASILEIRO DE GEOGRAFIA E ESTATÍSTICA IBGE. Manual técnico da vegetação brasileira. Rio de Janeiro: IBGE, 1992. 92p. (Série Manuais Técnicos em Geociências, 1).

JENKINS, W.R. A rapid centrifugation technique for separating nematodes from soil. Plant Disease Report, v.48, p.692, 1964.

JOHNSON, D.; VANDENKOORNHUYSE, P.J.; LEAKE, J.R.; GILBERT, L.; BOOTH, R.E.; GRIME, J.P.; YOUNG, J.P.W.; READ, D.J. Plant communities affect arbuscular mycorrhizal fungal diversity and community composition in grassland microcosms. New Phytologist, v.161, p.503-515, 2003.

KERNAGHAN, G. Mycorrhizal diversity: Cause and effect? Pedobiologia, v.49, p.511-520, 2005.

KOSKE, R.E. Distribution of VA mycorrhizal fungi along a latitudinal temperature gradient. Mycologia, v.79, p.55-68, 1987.

KOSKE, R.E.; TESSIER, B. A convenient, permanent slide mounting medium. Mycological Society of America Newsletter, v.34, p.59, 1983.

MAIA, L.C.; TRUFEM, S.F.B. Fungos micorrízicos vesículoarbusculares em solos cultivados no Estado de Pernambuco, Brasil. Revista Brasileira de Botânica, v.13, p.89-95, 1990. 
MANLY, B.F.J. Multivariate statistical methods: a Primer. 2.ed. London: Chapman \& Hall, 1994. 215p.

MILANEZ, F.R.; MONTEIRO NETO, H. Nota prévia sobre micorriza no pinho do Paraná. Arquivos do Serviço Florestal, v.4, p.87-93, 1950.

MOREIRA, M.; BARETTA, D.; TSAI, S.M.; CARDOSO, E.J.B.N. Spore density and root colonization by arbuscular mycorrhizal fungi in preserved or disturbed Araucaria angustifolia (Bert.) O. Ktze. ecosystems. Scientia Agricola, v.63, p.380-385, 2006.

MOREIRA-SOUZA, M.; CARDOSO, E.J.B.N., Dependência micorrízica de Araucaria angustifolia (Bert.) O. Ktze. sob doses de fósforo. Revista Brasileira de Ciência do Solo, v.26, p.905-912, 2002.

MOREIRA-SOUZA, M.; TRUFEM, S.F.B.; GOMES-DA-COSTA, S.M.; CARDOSO, E.J.B.N. Arbuscular mycorrhizal fungi associated with Araucaria angustifolia (Bert.) O. Ktze. Mycorrhiza, v.13, p.211-215, 2003.

MORTON, J.B.; BENTIVENGA, S.P.; WHEELER, W.W. Germplasm in the International Collection of Arbuscular and Vesicular Arbuscular Mycorrhizal Fungi (INVAM) and procedures for culture development, documentation and storage. Mycotaxon, v.48, p.491-528, 1993.

MOUILLOT, D.; LEPRETTRE, A. A comparison of species diversity estimators. Research on Population Ecology, v.41, p.203215,1999

OLIVEIRA, M.; VENTURA, A. A ocorrência de micorriza em Araucaria angustifolia (Bert.) O. Ktze e Podocarpus lamberti. São Paulo: Serviço Florestal, 1952, 5p. (Edições e propaganda, 25).

PARR, J.F.; PAPENDICK, R.I.; HORNICK, S.B.; MEYER, R.E. Soil quality: attributes and relationship to alternative and sustainable agriculture. American Journal of Alternative Agriculture, v.7, p.5-10, 1992.
PICONE, C. Diversity and abundance of arbuscular-mycorrhizal fungus spores in tropical forest and pasture. Biotropica, v.32, p.734-750, 2000.

SAS Institute. SAS/STAT, Release 6.2. Cary: SAS Institute Inc., 1996.

SCHENCK, N.C.; PÉREZ, Y. Manual for the identification of VA mycorrhizal fungi. 3.ed. Gainesville: Synergistic, 1990.

SMITH, S.E.; BARKER, S.J. Plant phosphate transporter genes help harness the nutritional benefits of arbuscular mycorrhizal symbiosis. Trends Plant Science, v.75, p.189-190, 2002.

TRUFEM, S.B. Aspectos ecológicos de fungos micorrízicos vesículoarbusculares da mata tropical úmida da Ilha do Cardoso, SP, Brasil. Acta Botanica Brasilica, v.4, p.31-45, 1990.

VAN DER HEIJDEN, M.; KLIRONOMOS, J.; URSIC, M.; MOUTOGLIS, P.; STREITWOLF-ENGEL, R.; BOLLER, T.; WIEMKEN, A.; SANDERS, I. Mycorrhizal fungal diversity determines plant biodiversity, ecosystem variability and productivity. Nature, v.396, p.69-72, 1998.

VIERHEILIG, H.; COUGHLAN, A.P.; WYSS, U.; PICHÉ, Y. Ink and vinegar, a simple staining technique for arbuscularmycorrhizal fungi. Applied and Environmental Microbiology, v.64, p.5004-5007, 1998.

WARDLE, D.A. Communities and Ecosystems: Linking Aboveground and Belowground Components. Princeton: Princeton University Press, 2002. (Monographs in Population Biology, 34).

ZANDAVALLI, R.B.; DILLENBURG, L.R.; SOUZA, P.V.D. Growth responses of Araucaria angustifolia (Araucariaceae) to inoculation with the mycorrhizal fungus Glomus clarum. Applied Soil Ecology, v.25, p.245-255, 2004.

Received September 29, 2006

Accepted May 25, 2007 